\title{
Diagnoza kształcenia zdalnego wśród studentów i doktorantów z niepełnosprawnościami w sytuacji pandemii COVID-19 - wybrane zagadnienia raportu z badań
}

\author{
Anna Gutowska \\ (D) https://orcid.org/0000-0001-5258-8772 \\ Uniwersytet Łódzki \\ Joanna Sztobryn-Giercuszkiewicz \\ (D) https://orcid.org/0000-0002-2148-4345 \\ Uniwersytet Łódzki
}




\title{
Streszczenie
}

Celem publikacji jest prezentacja wybranych wyników badań, dotyczących zdalnego kształcenia studentów z niepełnosprawnościami w polskich uczelniach w czasie pandemii COVID-19. Autorki zebrały opinie 291 studentów z różnymi niepełnosprawnościami i dokonały analizy realizacji procesu kształcenia zdalnego w sytuacji pandemii z perspektywy tej grupy. W publikacji przedstawiono doświadczenia badanych w zakresie różnych obszarów kształcenia zdalnego, jego pozytywnych i negatywnych aspektów, oceny edukacji online od strony merytorycznej i organizacyjnej, jego wpływu na sferę psychiczną, fizyczną i społeczną badanych. Przedstawiono także opinie studentów z niepełnosprawnościami na temat otrzymywanego i oczekiwanego wsparcia oraz oczekiwania badanych, co do kształcenia w systemie zdalnym, w zakresie lepszego dopasowania do ich potrzeb. W badaniach uwzględniono perspektywę studentów $\mathrm{z}$ różnymi rodzajami i stopniami niepełnosprawności, reprezentujących różne typy uczelni, różne kierunki, stopnie i etapy studiowania.

\section{Słowa kluczowe}

kształcenie zdalne, pandemia COVID-19, raport, studenci i doktoranci z niepełnosprawnościami.

\section{Diagnosis of distance education among students and doctoral students with disabilities in the situation of the COVID-19 pandemic - selected issues of the research reporti}

\begin{abstract}
The aim of the publication is to present selected results of the research on distance education of students with disabilities in Polish higher education institutions during COVID-19 pandemics. The authors gathered the opinions from 291 students with various disabilities, and they performed the analysis of the implementation of online education process in pandemics from the perspective of this specific group. The publication includes the respondents' experiences referring to different areas of distance education and to its positive and negative aspects. It also offers the assessment of online learning from the substantive and organisational angle and from the perspective of its influence on the psychic, physic and social sphere of the respondents' functioning. Also the opinions of students with disabilities on the support they expected and the one they received and on their expectations for distance education to be better adjusted to their needs are included in the publication. Perspectives of students with different disability types and levels, representing various higher education institutions, different study programmes, cycles and stages of studying were taken into consideration in the research.
\end{abstract}

\section{Keywords}

COVID-19 pandemic, remote education, report, students and doctoral students with disabilities. 
W Polsce w ostatnich latach (zwłaszcza dwóch ostatnich dekadach), liczba studentów z niepełnosprawnościami istotnie wzrosła. Poprawie uległa także ich sytuacja na wyższych uczelniach (Gajdzica, 2015). Powodów można upatrywać w wielu czynnikach, między innymi wzroście świadomości społecznej czy obowiązujących przepisach prawnych ${ }^{1}$. Powoli, ale znikają bariery architektoniczne, cyfrowe i mentalne. Również polskie uczelnie ulegają przemianom, zarówno w aspekcie infrastrukturalnym, jak i świadomościowym (Sztobryn-Giercuszkiewicz, 2016, s. 100). Rzeczywistość jest jednak często nieprzewidywalna, a nawet zaskakująca, czego dowodem okazał się rok 2020, kiedy to ogólnoświatowa pandemia COVID-19 zmusiła instytucje edukacyjne do niemal natychmiastowego przestawienia się na nauczanie na odległość. Nagle, w większości bez większej wiedzy, umiejętności, odpowiednich metod i narzędzi, zarówno nauczyciele, jak i studenci zmuszeni zostali do realizacji swoich zadań w sposób zdalny. Ta bezprecedensowa zmiana zaszła w niespotykanie szybkim tempie, zaledwie w kilka miesięcy. Wielu studentów nie doświadczyło nigdy wcześniej formalnej edukacji zdalnej, w tym również studenci z niepełnosprawnościami. Koniecznym zatem wydawało się zbadanie, czy i jakie problemy ujawniły się w tej sytuacji wśród studiujących osób z niepełnosprawnościami.

Prezentowany tekst jest rezultatem badań i analiz, których celem była identyfikacja problemów związanych z kształceniem zdalnym studentów i doktorantów w sytuacji pandemii COVID-19. Finalnie powstała diagnoza, której wybrane wyniki zostały poniżej zaprezentowane. Wnioski mogą być przyczynkiem do weryfikacji systemów e-nauczania i dostosowania procesu kształcenia do potrzeb i możliwości studentów z niepełnosprawnościami. Należy podkreślić, że prezentowana publikacja ma charakter raportu z danych empirycznych uzyskanych w rezultacie przeprowadzonego badania, a autorki - ze względu na obszerność i wielowątkowość zebranego materiału, w tym miejscu jedynie sprawozdają jego główne statystyczne wyniki.

W ramach projektu badawczego przeprowadzono anonimowe badanie ankietowe w grupie 291 niepełnosprawnych studentów i doktorantów kształcących się w polskich uczelniach. W badaniu uczestniczyli studenci ze specjalnymi potrzebami edukacyjnymi, niekoniecznie legitymujący się formalnym orzeczeniem o niepełnosprawności, ale znajdujący się w bazach jednostek do spraw osób niepełnosprawnych poszczególnych uczelni. Badanie zostało przeprowadzone w październiku 2020 r. W tekście zaprezentowano wybrane zagadnienia $\mathrm{z}$ raportu oraz wnioski z kompleksowego badania opinii niepełnosprawnych studentów kształcących się zdalnie.

\footnotetext{
${ }^{1}$ Do najistotniejszych aktów prawnych należy zaliczyć:

1. Konwencję ONZ o prawach osób niepełnosprawnych, ratyfikowaną przez Polskę w $2012 \mathrm{r}$.

2. Ustawę z dnia 20 lipca 2018 r. - Prawo o szkolnictwie wyższym i nauce.

3. Ustawę z dnia 19 lipca 2019 r. o zapewnieniu dostępności osobom ze szczególnymi potrzebami.
} 


\section{METODOLOGIA BADAŃ}

Bezpośrednią motywacją do podjęcia badań były obserwacje i osobiste doświadczenie autorek badania, będących pełnomocnikami rektorów ds. osób niepełnosprawnych dwóch największych łódzkich ośrodków akademickich: Uniwersytetu Łódzkiego i Politechniki Łódzkiej. Pierwotnym zamysłem było przeprowadzenie badania wyłącznie wśród studentów łódzkich uczelni, jednak w toku analizy koncepcji badań postanowiono poszerzyć próbę badawczą o niepełnosprawnych studentów kształcących się zdalnie w innych polskich ośrodkach akademickich. W dystrybucji ankiet elektronicznych pośredniczyły Biuro Obsługi Osób Niepełnosprawnych Politechniki Łódzkiej oraz Akademickie Centrum Wsparcia Uniwersytetu Łódzkiego. W rezultacie przeprowadzono 142 ankiety wśród studentów Politechniki Łódzkiej oraz Uniwersytetu Łódzkiego oraz 149 ankiet wśród studentów innych uczelni wyższych zlokalizowanych na terenie całego kraju (łącznie 291 osób).

Problemy badawcze zogniskowano wokół kilku obszarów: doświadczenia badanych ze zdalną edukacją, obszaru społeczno-psychologicznego oraz metodyczno-organizacyjnego związanego ze zdalną edukacją. Zbadano także pozytywne i negatywne aspekty kształcenia na odległość.

Techniką badawczą wykorzystaną do realizacji badania było CAWI (Computer Assisted Web Interview) - wspomagany komputerowo wywiad wypełniany przez respondenta $\mathrm{w}$ formie online. Obecnie metoda CAWI jest jedną z bardziej popularnych oraz najszybciej rozwijających się metod badawczych. W porównaniu do innych narzędzi, dzięki poczuciu anonimowości i możliwości udziału w badaniu w terminie dogodnym dla respondenta, pozwala zgromadzić bardziej rzetelne dane. Istotnym elementem, o który zadbały autorki, była taka konstrukcja narzędzia badawczego (ankiety online), by było one dostosowane do potrzeb osób z różnymi rodzajami niepełnosprawności i spełniało standardy dostępności cyfrowej (Sztobryn-Giercuszkiewicz, 2020).

Kwestionariusz ankiety składał się z pytań zamkniętych, pytań z możliwością wielokrotnego wyboru, z kafeterią odpowiedzi oraz pytań otwartych umożliwiających swobodną wypowiedź respondenta. Dane uzyskane w trakcie realizacji badań poddane zostały analizie, zarówno ilościowej, jak i jakościowej, a wybrane wyniki przedstawiono poniżej.

\section{WYNIKI BADAŃ}

Wyniki badań zostały przedstawione w sferze kilku zagadnień badawczych: cech społeczno-demograficznych badanej próby, doświadczenia badanych ze zdalną edukacją, obszaru społeczno-psychologicznego związanego ze zdalną edukacją, pozytywnych i negatywnych aspektów kształcenia na odległość. 


\section{CECHY SPOŁECZNO-DEMOGRAFICZNE BADANEJ PRÓBY}

Jeżeli chodzi o płeć respondentów, struktura badanej próby była równoliczna. W badaniach uczestniczyło 49,1\% mężczyzn oraz 50,9\% kobiet. Wiek badanych wahał się od 19 do 56 lat. Średnia wieku wynosiła 24,4 lat. Największą grupę respondentów stanowili niepełnosprawni studenci w wieku 22 lat -14,4\%, 21 lat - 12,4\%, 20 lat - 11,7\%, 24 lat - 11,0\% oraz 23 lat i 25 lat - po 10,3\% ogółu badanych. Ponad połowa badanych $(56,4 \%)$ studiuje na studiach pierwszego stopnia (studia licencjackie/inżynierskie). Mniej niż co trzeci uczestnik badania $(31,9 \%)$ studiuje na studniach drugiego stopnia (studia magisterskie), natomiast $11,7 \%$ badanych studiuje na studiach jednolitych magisterskich.

Ponad połowa niepełnosprawnych studentów uczestniczących w badaniu (57,7\%) posiada lekki stopień niepełnosprawności. Więcej niż co trzeci uczestnik badania $(34,4 \%)$ ma umiarkowany stopień niepełnosprawności. Zdecydowanie mniejszy odsetek badanych $(5,2 \%)$ posiada znaczny stopień niepełnosprawności, natomiast $2,7 \%$ badanych nie posiada orzeczonego stopnia o niepełnosprawności, ale jest osobą niepełnosprawną $\mathrm{z}$ orzeczeniem ZUS. Ankietowani studenci posiadają różnego rodzaju niepełnosprawności. Niektóre badane osoby mają niepełnosprawność sprzężoną - co najmniej dwa rodzaje niepełnosprawności występujące u jednej osoby łącznie, dlatego suma wskazań jest większa niż $100 \%$. Największa grupa badanych $(23,7 \%)$ wskazała dysfunkcję narządu ruchu. $14,8 \%$ wymieniło inne schorzenia, $\mathrm{w}$ tym schorzenia: endokrynologiczne, metaboliczne, zaburzenia enzymatyczne, choroby zakaźne i odzwierzęce, zeszpecenia oraz choroby układu krwiotwórczego. 13,1\% wskazało choroby neurologiczne. Więcej niż co dziesiąty uczestnik badania wymienił choroby narządu wzroku $(12,4 \%)$ oraz choroby psychiczne $-11,3 \%$. Zaburzenia głosu, mowy i choroby słuchu wskazało $8,6 \%$ badanych, natomiast $6,5 \%$ wymieniło choroby układu pokarmowego. Wszystkie rodzaje niepełnosprawności posiadane przez badanych zostały przedstawione na wykresie 1 .

Wykres 1 . Charakterystyka badanej próby z uwzględnieniem rodzaju niepełnosprawności $(\mathrm{N}=291, \mathrm{w} \%)$

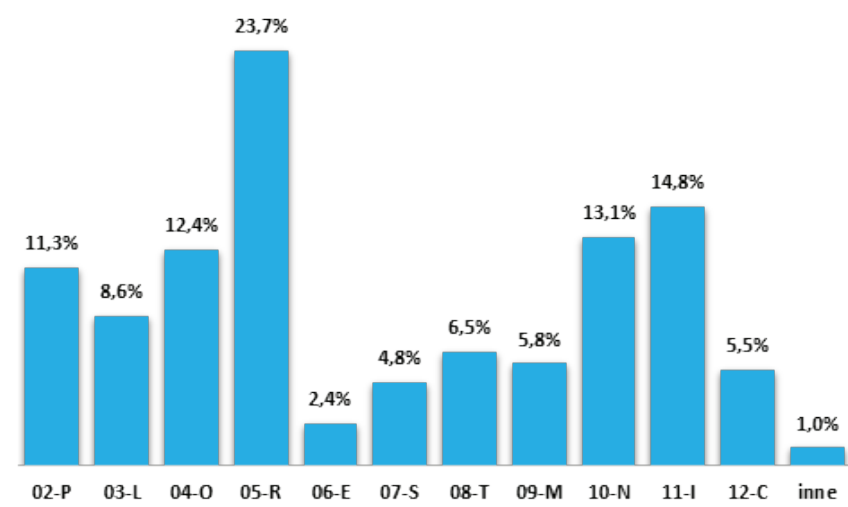

Źródło: opracowanie własne. 
Wyraźna większość uczestniczących w badaniu studentów (82,8\%, 241 osób) nie miała żadnych doświadczeń ze zdalnym nauczaniem przed pandemią. Jest to blisko pięć razy więcej niż liczba studentów, którzy uczyli się w sposób zdalny. Odsetek studentów uczących się od dawna w sposób zdalny wynosiła tylko 17,2\% (50 osób). Biorąc pod uwagę tylko studentów, którzy uczyli się zdalnie przed wybuchem pandemii (50 osób), to 60,0\% (30 osób) z nich uczyło się zdalnie 1-2 przedmiotów, 32,0\% (16 osób) pobierało zdalną naukę studiując co najmniej pięć przedmiotów, wyraźna mniejszość 8,0\% na 3-4 przedmioty i są to tylko 4 osoby.

W ocenie zadowolenia $\mathrm{z}$ e-learningu studenci, którzy uczyli się w ten sposób przed pandemią (50 osób), niemal równo dzielą się na niezadowolonych - 56,0\% (28osób) i zadowolonych - 44,0\% (22 osoby). Nieznaczna jest więc przewaga osób niezadowolonych. Niepełnosprawni studenci, którzy kształcili się uprzednio w formie zdalnej, poproszeni zostali o uzasadnienie wcześniejszej opinii dotyczącej takiej formy kształcenia. Respondenci byli najbardziej zadowoleni z takich aspektów, jak: dobre przygotowanie nauczania zdalnego, możliwość pracy w dwóch programach jednocześnie, dostępność materiałów do nauki przez cały semestr, brak problemu związanego z dojazdem na uczelnię, wygodna forma nauki, możliwość połączenia edukacji z pracą, możliwość udziału w zajęciach z dowolnego miejsca, oszczędność czasu i pieniędzy. Do negatywnych, wcześniejszych doświadczeń związanych ze zdalną edukacją studenci zaliczyli: trudności ze skupieniem się na nauce $\mathrm{w}$ domu, utrudnienia związane z połączeniem internetowym oraz $\mathrm{z}$ komunikacją, brak kontaktów interpersonalnych, gorszy kontakt z wykładowcą, brak zajęć praktycznych, słabe rezultaty nauki, brak motywacji do nauki w domu.

Relatywnie najwyższy odsetek uczestników badania (biorąc pod uwagę całą próbę) deklarowało, że w dużym stopniu byli przygotowani do zdalnego nauczania - 32,0\% (93 osoby). Na zbliżonym poziomie - 30,2\% (88 osób) jest odsetek osób przygotowanych w średnim stopniu. Przygotowani w małym stopniu stanowią 13,4\% (39 osób), a w stopniu bardzo małym 11,7\% (34 osoby). Tylko 6,9\% (20 osób) deklaruje przygotowanie do e-learningu w bardzo dużym stopniu, a 5,8\% (17 osób) nie ma zdania. Ogółem przygotowanych (biorąc pod uwagę przygotowanie w dużym i bardzo dużym stopniu) jest więcej $(38,8 \%)$ niż nieprzygotowanych $(25,1 \%)$, tj. przygotowanych w małym i bardzo małym stopniu łącznie.

Wyraźna większość badanych 84,5\% (246 osób) uczyła się zdalnie we własnym domu, 10,0\% (29 osób) w wynajętym mieszkaniu, 2,7\% (8 osób) w akademiku, 2,1\% (6 osób) u znajomych, 0,7\% (2 osoby) w innym miejscu (u rodziców partnerki oraz w ośrodku rehabilitacyjnym). Zdecydowana większość uczestników badania deklaruje, że ma możliwość nauki w samodzielnym pomieszczeniu, jest to 83,2\% (242 osoby). Tylko 16,8\% (49 osób) realizuje zajęcia zdalne w pomieszczeniu, które z kimś dzieli. Większość studentów 82,5\% (240 osób) posiadało odpowiedni sprzęt w momencie przejścia na zdalną naukę. 17,5\% (51 osób) takiego sprzętu nie miało. W grupie 51 studentów, którzy nie mieli odpowiedniego sprzętu 41,0\% (21 osób) zadeklarowało konieczność zakupu sprzętu komputerowego i oprogramowania. Nieco mniej - 39,2\% (20 osób) musiało postarać 
się o dostęp do internetu, 37,3\% (19 osób) zakupiło słuchawki, 29,4\% (19 osób) dokonało zakupu skanera, 25,5\% (13 osób) zakupu drukarki, 11,8\% (6 osób) telefonu i 7,8\% (4 osoby) dokonało innych zakupów (kamera, mikrofon).

Najczęściej wykorzystywanym urządzeniem do zdalnej nauki jest laptop, korzysta z niego zawsze $48,8 \%$ (142 osoby). Najmniej popularnym urządzeniem do tego celu jest tablet - aż 77,3\% (225 osób) ankietowanych podaje, że nigdy nie korzysta z tabletu. Z laptopa często korzysta 33,3\% badanych studentów (97 osób), odpowiedzi czasami, rzadko i nigdy dla laptopa są na niskim poziomie, odpowiednio jest to 7,2\% (21 osób), 4,5\% (13 osób), 6,2\% (18 osób). Z kolei z tabletu rzadko korzysta 9,6\% (28 osób), czasami 7,6\% (22 osoby), często 3,8\% (11 osób), zawsze 1,7\% (5 osób). W przypadku korzystania z tabletu rysuje się trend od odpowiedzi wskazujących na brak korzystania (wysoki odsetek) do regularnego korzystania - bardzo niski odsetek. Studentów pytano również o korzystanie z telefonu i komputera stacjonarnego. Zawsze korzysta $\mathrm{z}$ telefonu $11,3 \%$ ankietowanych (33 osoby), często $21,0 \%$ (61 osób), czasami 30,2\% (88 osób), rzadko 23,4\% (68 osób), nigdy $14,1 \%$ (41 osób). W przypadku komputera stacjonarnego widoczna jest przewaga nigdy niekorzystających z tego urządzenia do zdalnej nauki 56,7\% (165 osób), rzadko korzysta z niego 10,0\% (29 osób), czasami 13,7\% (40 osób), zawsze z komputera stacjonarnego w celach e-learningu korzysta 12,7\% (37 osób). Podsumowując - wśród urządzeń zawsze wykorzystywanych do zdalnej nauki kluczowe znaczenie ma laptop, następnie komputer stacjonarny i telefon, następnie tablet. Dla urządzeń często używanych do zdalnej nauki kolejność jest analogiczna. Relatywnie najwyższy odsetek studentów korzysta z telefonu sporadycznie.

Tabela 1. Z jakiego urządzenia korzysta Pani/Pan najczęściej, ucząc się zdalnie? $(\mathrm{N}=291, \mathrm{w} \%)$

\begin{tabular}{|l|r|r|r|r|r|r|r|r|r|r|}
\hline & \multicolumn{2}{|c|}{ Nigdy } & \multicolumn{2}{c|}{ Rzadko } & \multicolumn{2}{c|}{ Czasami } & \multicolumn{2}{c|}{ Często } & \multicolumn{2}{c|}{ Zawsze } \\
\hline & $\mathbf{N}$ & $\mathbf{\%}$ & $\mathbf{N}$ & $\mathbf{\%}$ & $\mathbf{N}$ & $\mathbf{\%}$ & $\mathbf{N}$ & $\mathbf{\%}$ & $\mathbf{N}$ & $\mathbf{\%}$ \\
\hline Telefon & 41 & 14,1 & 68 & 23,4 & 88 & 30,2 & 61 & 21,0 & 33 & 11,3 \\
\hline Tablet & 225 & 77,3 & 28 & 9,6 & 22 & 7,6 & 11 & 3,8 & 5 & 1,7 \\
\hline Laptop & 18 & 6,2 & 13 & 4,5 & 21 & 7,2 & 97 & 33,3 & 142 & 48,8 \\
\hline $\begin{array}{l}\text { Komputer } \\
\text { stacjonarny }\end{array}$ & 165 & 56,7 & 29 & 10,0 & 20 & 6,9 & 40 & 13,7 & 37 & 12,7 \\
\hline
\end{tabular}

Źródło: opracowanie własne.

Jeśli chodzi o formę zajęć online, to w opinii ankietowanych studentów prowadzący zajęcia korzystają z udostępnienia materiałów dydaktycznych w postaci kursu na platformie e-learningowej: często - według 32,3\% (94 osób), czasami - zdaniem 28,2\% (82 osób), bardzo często - zdaniem 21,0\% (61 osób), rzadko - według 11,0\% (32 osoby), odpowiedzi „wcale” udzieliło 7,6\% (22 osoby). E-wykład „na żywo” z wykorzystaniem komunikacji audio/video/prezentacji jest częstą formą zdaniem 34,0\% (99 osób), bardzo często 
zdaniem 28,2\% (82 osoby), odpowiedzi „czasami” udzieliło 22,0\% (64 osoby), „rzadko” 11,0\% (32 osoby), „wcale” 4,8\% (14 osób). Nagranie e-wykładu audio/video do odtworzenia w dowolnym czasie jest czasami wykorzystywane według 33,7\% (98 studentów), rzadko zdaniem $27,8 \%$ (81 studentów), wcale według $25,4 \%$ (74 osoby), odpowiedzi „często” udzieliło 9,6\% (28 osób), „bardzo często” 3,4\% (10 osób). Prezentacja w formie pliku PowerPoint/PDF jest udostępniana „często”, twierdzi 41,6\% (121 osób), „czasami” 24,4\% (71 osób), „bardzo często” 16,8\% (49 osób), „rzadko” 12,4\% (36 osób), „wcale” 4,8\% (14 osób). Udostępnienie materiałów dydaktycznych za pomocą poczty elektronicznej jest często wykorzystywane przez wykładowców zdaniem 36,4\% studentów (106 osób), czasami - zdaniem 24,7\% (72 studentów), bardzo często według 16,5\% (48 studentów), odpowiedzi „rzadko" udzieliło 14,8\% (43 ankietowanych), „wcale” 7,6\% (22 osoby). Udostępnienie innych materiałów $\mathrm{w}$ formie elektronicznej do samodzielnego opracowania wykładowcy wykorzystują często zdaniem 31,6\% (92 osób), czasami w opinii 28,5\% (83 osób), rzadko według 21,0\% (61 osób), odpowiedzi skrajnych „wcale” i „bardzo często” udzieliło odpowiednio 9,6\% (28 osób) i 9,3\% (27 osób). Podsumowując - najczęściej wykorzystywaną formą zajęć online (suma odpowiedzi „często” i „bardzo często”) jest e-wykład na żywo, a najrzadziej nagranie e-wykładu audio/video do odtworzenia w dowolnym czasie. Opisane wyniki przedstawia wykres nr 2 .

Wykres 2. Z jakiej formy zajęć online korzystali prowadzący zajęcia na uczelni?

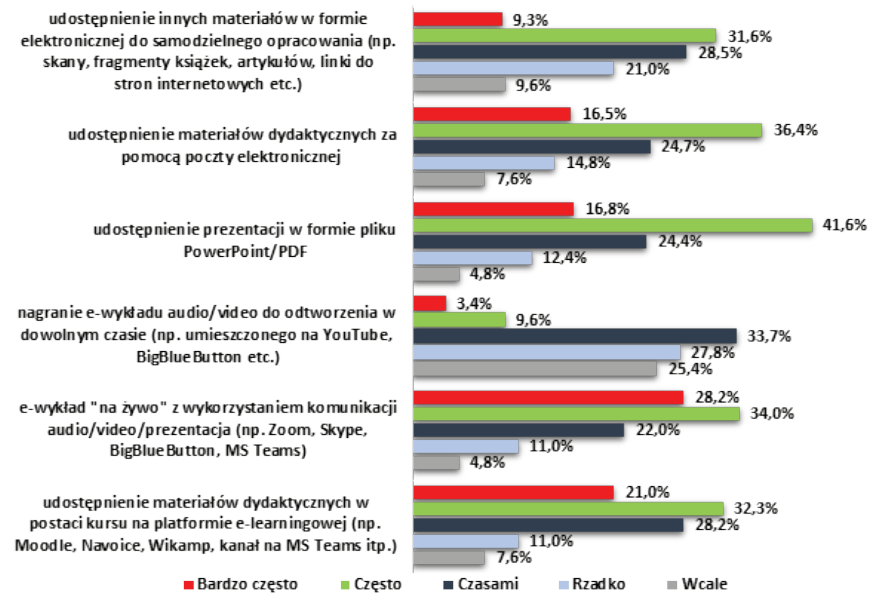

Źródło: opracowanie własne.

Wymienione w poprzednim akapicie formy zdalnej nauki studenci oceniali pod kątem przydatności, mogąc wskazać dowolną liczbę odpowiedzi. Najwięcej wskazań zyskał

e-wykład na żywo: 64,6\% odpowiedzi (188 osób), następnie udostępnienie materiałów dydaktycznych w postaci kursu na platformie e-learningowej - 58,1\% (169 osób), udostępnienie prezentacji w formie pliku PowerPoint/PDF - 51,2\% wskazań (149 osób), nagranie e-wykładu audio/video do odtworzenia w dowolnym czasie - 50,9\% odpowiedzi 
(148 osób). Poniżej 50\% wskazań znalazły się: udostępnienie materiałów dydaktycznych za pomocą poczty elektronicznej - 26,1\% odpowiedzi (76 osób), udostępnienie innych materiałów w formie elektronicznej do samodzielnego opracowania - 16,2\% wyborów (47 osób), inne formy zajęć wskazało 1,4\% (4 osoby). Ilustracją danych jest tabela nr 2.

Tabela 2. Które z ocenianych form zajęć online są Pani/Pana zdaniem najlepsze do nauki zdalnej, które formy Pani/Pan preferuje? (N=291, w \%)

\begin{tabular}{|l|r|r|}
\hline Odpowiedź & $\mathbf{N}$ & $\mathbf{\%}$ \\
\hline $\begin{array}{l}\text { e-wykład „na żywo” z wykorzystaniem komunikacji audio/video/pre- } \\
\text { zentacja (np. Zoom, Skype, BigBlueButton, MS Teams) }\end{array}$ & 188 & 64,6 \\
\hline $\begin{array}{l}\text { udostępnienie materiałów dydaktycznych w postaci kursu na platformie } \\
\text { e-learningowej (np. Moodle, Navoice, Wikamp, kanał na MS Teams) }\end{array}$ & 169 & 58,1 \\
\hline udostępnienie prezentacji w formie pliku PowerPoint/PDF & 149 & 51,2 \\
\hline $\begin{array}{l}\text { nagranie e-wykładu audio/video do odtworzenia w dowolnym czasie } \\
\text { (np. umieszczonego na YouTube, BigBlueButton) }\end{array}$ & 148 & 50,9 \\
\hline $\begin{array}{l}\text { udostępnienie materiałów dydaktycznych za pomocą poczty } \\
\text { elektronicznej }\end{array}$ & 76 & 26,1 \\
\hline $\begin{array}{l}\text { udostępnienie innych materiałów w formie elektronicznej do } \\
\text { samodzielnego opracowania (np. skany, fragmenty książek, artykułów, } \\
\text { linki do stron internetowych) }\end{array}$ & 47 & 16,2 \\
\hline inne formy zajęć online & 4 & 1,4 \\
\hline
\end{tabular}

Źródło: opracowanie własne.

Na pytanie o to, z jakich narzędzi wsparcia korzystali prowadzący zajęcia, w odpowiedziach badanych studentów dominują odpowiedzi „wcale”: 73,9\% (215 osób) dla Adobe Connect; dla Cisco WebEx Meetings 72,2\% (210 osób); ClickMeeting 70,8\% (206 osób); Discord 56,7\% (165 osób); dla pozostałych narzędzi (komunikator, Zoom, platforma e-learningowa, MS Teams, e-mail) odpowiedzi „wcale” wystąpiły poniżej 50,0\%. Biorąc pod uwagę sumę odpowiedzi „wcale” i „rzadko” najrzadziej wykorzystywanymi narzędziami są Adobe Connect, Cisco WebEx Meetings, ClickMeeting. Odpowiedzi „czasami” odnotowano dla narzędzi w następującej kolejności od najwyższego odsetka: e-mail 26,1\% (76 osób), platforma e-learningowa 25,1\% (73 osoby), Discord 16,8\% (49 osób), Zoom i komunikator (np. Messenger) po 16,5\% (48 osób), MS Teams 13,1\% (38 osób), ClickMeeting 12,4\% (36 osób), Adobe Connect 11,3\% (33 osoby), Cisco WebEx Meetings $10,0 \%$ (29 osób). Biorąc pod uwagę odpowiedzi „bardzo często” na pierwszym miejscu pojawił się MS Teams 40,5\% (118 osób), e-mail 27,5\% (80 osób), należy jednak zauważyć, że w odpowiedziach „bardzo często” żaden rezultat nie sięgnął 50,0\%, pozostałe wyniki są już jednocyfrowe i znajdują się w tabeli 3. Podsumowując, prowadzący zajęcia rzadko korzystają z narzędzi wsparcia zajęć online, najwyższą popularnością cieszy się MS Teams oraz e-mail. 
Tabela 3. Z jakich narzędzi wsparcia zajęć online korzystali prowadzący zajęcia? $(\mathrm{N}=291, \mathrm{w} \%)$

\begin{tabular}{|l|r|r|r|r|r|r|r|r|r|r|}
\hline & \multicolumn{2}{|c|}{ Wcale } & \multicolumn{2}{c|}{ Rzadko } & \multicolumn{2}{c|}{ Czasami } & \multicolumn{2}{c|}{ Często } & \multicolumn{2}{c|}{$\begin{array}{l}\text { Bardzo } \\
\text { często }\end{array}$} \\
\hline & $\mathbf{N}$ & $\mathbf{\%}$ & $\mathbf{N}$ & $\mathbf{\%}$ & $\mathbf{N}$ & $\mathbf{\%}$ & $\mathbf{N}$ & $\mathbf{\%}$ & $\mathbf{N}$ & $\%$ \\
\hline MS Teams & 45 & 15,5 & 23 & 7,9 & 38 & 13,1 & 67 & 23,0 & 118 & 40,5 \\
\hline $\begin{array}{l}\text { Platforma } \\
\text { e-learningowa, } \\
\text { np. Moodle }\end{array}$ & 65 & 22,3 & 59 & 20,3 & 73 & 25,1 & 66 & 22,7 & 28 & 9,6 \\
\hline Zoom & 137 & 47,1 & 56 & 19,2 & 48 & 16,5 & 33 & 11,3 & 17 & 5,8 \\
\hline Discord & 165 & 56,7 & 43 & 14,8 & 49 & 16,8 & 27 & 9,3 & 7 & 2,4 \\
\hline $\begin{array}{l}\text { Cisco WebEx } \\
\text { Meetings }\end{array}$ & 210 & 72,2 & 38 & 13,1 & 29 & 10,0 & 8 & 2,7 & 6 & 2,1 \\
\hline Adobe Connect & 215 & 73,9 & 35 & 12,0 & 33 & 11,3 & 5 & 1,7 & 3 & 1,0 \\
\hline E-mail & 8 & 2,7 & 29 & 10,0 & 76 & 26,1 & 98 & 33,7 & 80 & 27,5 \\
\hline $\begin{array}{l}\text { Komunikator, } \\
\text { np. Messenger }\end{array}$ & 145 & 49,8 & 38 & 13,1 & 48 & 16,5 & 38 & 13,1 & 22 & 7,6 \\
\hline ClickMeeting & 206 & 70,8 & 18 & 6,2 & 36 & 12,4 & 21 & 7,2 & 10 & 3,4 \\
\hline
\end{tabular}

Źródło: opracowanie własne.

Uczestnicy badania oceniali poszczególne narzędzia wsparcia, wymienione w poprzednim paragrafie, pod względem przydatności do nauki zdalnej. Mogli zaznaczyć dowolną liczbę narzędzi. Na pierwszym miejscu (64,3\% wskazań - 187 osób) znalazło się MS Teams, na kolejnym (50,9\% - 148 osób) e-mail. Kolejne narzędzia zyskały poniżej $50,0 \%$ wskazań. Platformy e-learningowe wymieniło 41,2\% badanych (120 osób), Zoom 25,4\% (74 osoby), Discord 22,3\% (65 osób), komunikatory 21,3\% (62 osoby), ClickMeeting 7,2\% (21 osób), Cisco WebEx Meetings 3,4\% (10 osób), inne narzędzia wsparcia takie jak: Skype, materiały do zajęć i nauki w chmurze, Google Meets, SMS, BigBlueButton - 3,1\% (9 osób), Adobe Connect 2,7\% (8 osób). Przedstawione dane znajdują się na w tabeli 4 .

Tabela 4. Które z wymienionych narzędzi wsparcia są Pani/Pana zdaniem najlepsze do nauki zdalnej, które narzędzia Pani/Pan preferuje? ( $\mathrm{N}=291$, w \%)

\begin{tabular}{|l|r|r|}
\hline Odpowiedź & $\mathbf{N}$ & $\mathbf{\%}$ \\
\hline MS Teams & 187 & 64,3 \\
\hline E-mail & 148 & 50,9 \\
\hline Platforma e-learningowa, np. moodle & 120 & 41,2 \\
\hline Zoom & 74 & 25,4 \\
\hline
\end{tabular}




\begin{tabular}{|l|r|r|}
\hline Discord & 65 & 22,3 \\
\hline Komunikator, np. Messenger & 62 & 21,3 \\
\hline ClickMeeting & 21 & 7,2 \\
\hline Cisco WebEx Meetings & 10 & 3,4 \\
\hline Inne & 9 & 3,1 \\
\hline Adobe Connect & 8 & 2,7 \\
\hline
\end{tabular}

Źródło: opracowanie własne.

W odpowiedzi na pytanie o dodatkowe formy interakcji, z jakich korzystają prowadzący zajęcia e-learningowe, dominują odpowiedzi „wcale”, nie są one jednak tak przeważające, jak w przypadku narzędzi wsparcia zajęć online. 51,9\% ankietowanych studentów (151 osób) podaje, że wykładowcy wcale nie korzystają z rozmów telefonicznych, 38,5\% (112 osób) twierdzi, że wykładowcy nie korzystają z quizów. Odpowiedzi „bardzo często” nie są popularne wśród uczestników badania, najwyższy poziom to 15,1\% (44 osoby) dla rozmowy online i 10,7\% (31 osób) dla komunikacji za pomocą czatu. Biorąc pod uwagę sumę odpowiedzi „bardzo często” i „często”, najwyższą popularnością cieszą się konsultacje za pomocą rozmowy online, na drugim miejscu są konsultacje za pomocą czatu. W odpowiedziach „czasami” przeważa komunikacja za pomocą czatu 32,3\% (94 osoby) oraz konsultacja za pomocą rozmowy online 30,6\% (89 osób).

Tabela 5. Z jakich dodatkowych form interakcji korzystali prowadzący zajęcia na Pani/ Pana uczelni? Określ na skali częstotliwość wykorzystania dodatkowych form interakcji? (N=291, w \%)

\begin{tabular}{|l|r|r|r|r|r|r|r|r|r|r|}
\hline & \multicolumn{2}{|c|}{ Wcale } & \multicolumn{2}{c|}{ Rzadko } & \multicolumn{2}{c|}{ Czasami } & \multicolumn{2}{c|}{ Często } & \multicolumn{2}{c|}{$\begin{array}{l}\text { Bardzo } \\
\text { często }\end{array}$} \\
\hline & $\mathrm{N}$ & $\%$ & $\mathrm{~N}$ & $\%$ & $\mathrm{~N}$ & $\%$ & $\mathrm{~N}$ & $\%$ & $\mathrm{~N}$ & $\%$ \\
\hline $\begin{array}{l}\text { Komunikacja za } \\
\text { pomocą czatu }\end{array}$ & 33 & 11,3 & 56 & 19,2 & 94 & 32,3 & 77 & 26,5 & 31 & 10,7 \\
\hline $\begin{array}{l}\text { Konsultacje za } \\
\text { pomocą rozmo- } \\
\text { wy online }\end{array}$ & 34 & 11,7 & 48 & 16,5 & 89 & 30,6 & 76 & 26,1 & 44 & 15,1 \\
\hline $\begin{array}{l}\text { Quizy (np. } \\
\text { Kahoot, } \\
\begin{array}{l}\text { MS Teams, } \\
\text { formularze } \\
\text { Google) }\end{array}\end{array}$ & 112 & 38,5 & 63 & 21,6 & 59 & 20,3 & 40 & 13,7 & 17 & 5,8 \\
\hline $\begin{array}{l}\text { Rozmowy } \\
\text { telefoniczne }\end{array}$ & 151 & 51,9 & 70 & 24,1 & 36 & 12,4 & 27 & 9,3 & 7 & 2,4 \\
\hline
\end{tabular}

Źródło: opracowanie własne. 
W ocenie dostosowania zajęć zdalnych do indywidualnych potrzeb związanych z niepełnosprawnością danej osoby przeważa odpowiedź „raczej tak”, której udzieliło 45,4\% ankietowanych (132 osoby). Odpowiedzi „zdecydowanie tak" udzieliło $28,2 \%$ ( 82 osoby), $22 \%$ (64 osoby) nie miało zdania. 3,4\% (10 osób) odpowiedziało, że zajęcia zdalne raczej nie są dostosowane do ich potrzeb, a 1,0\% (3 osoby), że zdecydowanie nie. Podsumowując, zajęcia zdalne są $\mathrm{w}$ mniejszym lub większym stopniu dostosowane do potrzeb 73,6\% uczestniczących w badaniu niepełnosprawnych studentów. Osoby, które uważają, że zajęcia zdalne nie są dostosowane do potrzeb osób niepełnosprawnych, poproszono o uzasadnienie takiej opinii. Dla badanych najważniejsze problemy to przede wszystkim: słaba komunikacja z prowadzącymi, skracanie zajęć przez wykładowców, przerzucanie całej pracy na studentów, brak możliwości zadania pytania w bezpieczny sposób, by nie narazić się na komentarze na prywatnym czacie grupy, wyciszanie przez innych studentów, łatwiejsze wykluczanie studentów niepełnosprawnych, brak reakcji opiekuna roku na nieprzyjemności, które były motywowane trudnościami wynikającymi z niepełnosprawności, brak czatu wideo podczas zajęć utrudniający zmotywowanie się, brak napisów, potrzeba tłumacza języka migowego, zacinanie się obrazu, wizyty w szpitalu uniemożliwiające systematyczny udział $\mathrm{w}$ wykładach na żywo, problemy $\mathrm{z}$ koncentracją podczas zajęć zdalnych, brak dostępności do wykładu po zakończeniu wykładu, np. na YouTube, komunikacja głosowa niezdająca egzaminu (dla osób niedosłyszących), konieczność wsparcia innej osoby, prowadzący niewłączający kamery. Inne wymieniane bariery, to m.in.: „nie widać prowadzącego" (jest to utrudnienie dla osób, które „czytają” $\mathrm{z}$ ust $\mathrm{z}$ racji niedosłuchu), brak umiejętności działania na takich kanałach informacji, brak kontaktów interpersonalnych, możliwość „ściągania”, za dużo czasu poświęconego na naukę zdalną.

Studenci zapytani o porównanie jakości zajęć stacjonarnych i zdalnych w każdej z badanych kategorii (wykłady, ćwiczenia, konwersatoria, laboratoria, seminaria, praktyki) wyżej ocenili zajęcia w formie tradycyjnej. Najwyższy odsetek przewagi zajęć tradycyjnych 76,6\% (223 osoby) dotyczy laboratoriów, na kolejnym miejscu z wynikiem 75,3\% (odpowiedzi 219 osób) są praktyki, następnie ćwiczenia 70,8\% (206 osób). Dla pozostałych trybów nauczania przewaga zajęć stacjonarnych nie jest tak wyraźna, jednak wciąż występuje: zaliczenia i egzaminy preferuje stacjonarnie $48,8 \%$ badanych (142 osoby), konwersatorium 40,9\% (119 osób), seminarium 39,9\% (116 osób), wykłady 37,1\% (108 osób). Jako bardziej wartościowe zajęcia w formie zdalnej najwyższy odsetek badanych studentów ocenił wykłady $34,0 \%$ (99 osób), następnie egzaminy i zaliczenia $25,4 \%$ (75 osób), seminarium 21,6\% (63 osoby), konwersatorium 21\% (61 osób), ćwiczenia $13,7 \%$ (40 osób), laboratoria 8,2\% (24 osoby), praktyki 8,2\% (24 osoby). Równoważność obydwu form kształcenia wskazano przede wszystkim dla konwersatorium 33,7\% (98 osób), seminarium 32,6\% (95 osób), wykładów 28,9\% (84 osoby), egzaminów i zaliczeń $25,4 \%$ (74 osoby), ćwiczeń 15,5\% (45 osób), dla praktyk oraz laboratoriów odsetki są na poziomie 11,7\% (34 osoby). Odsetki odpowiedzi „nie wiem” są marginalne.

Natomiast w ocenie różnych aspektów związanych ze zdalną edukacją przeważały odpowiedzi „przeciętnie”, wysoko ankietowani studenci oceniają tylko kontakty z prowadzącymi zajęcia. Przedstawione tu dane znajdują się w tabeli 6 . 
Tabela 6. Jak ocenia Pani/Pan następujące aspekty związane z edukacją zdalną? $(\mathrm{N}=291, \mathrm{w} \%)$

\begin{tabular}{|c|c|c|c|c|c|c|c|c|c|c|c|c|}
\hline & \multicolumn{2}{|c|}{$\begin{array}{l}\text { Bardzo } \\
\text { wysoko }\end{array}$} & \multicolumn{2}{|c|}{ Wysoko } & \multicolumn{2}{|c|}{$\begin{array}{l}\text { Przecięt- } \\
\text { nie }\end{array}$} & \multicolumn{2}{|c|}{ Nisko } & \multicolumn{2}{|c|}{$\begin{array}{c}\text { Bardzo } \\
\text { nisko }\end{array}$} & \multicolumn{2}{|c|}{$\begin{array}{l}\text { Nie wiem } \\
\text { / trudno } \\
\text { powie- } \\
\text { dzieć }\end{array}$} \\
\hline & $\mathbf{N}$ & $\%$ & $\mathbf{N}$ & $\%$ & $\mathbf{N}$ & $\%$ & $\mathbf{N}$ & $\%$ & $\mathbf{N}$ & $\%$ & $\mathbf{N}$ & $\%$ \\
\hline $\begin{array}{l}\text { Jakość zajęć } \\
\text { realizowanych } \\
\text { w trybie zdal- } \\
\text { nym }\end{array}$ & 22 & 7,6 & 85 & 29,2 & 126 & 43,3 & 30 & 10,3 & 18 & 6,2 & 10 & 3,4 \\
\hline $\begin{array}{l}\text { Wiedza zdobyta } \\
\text { podczas na- } \\
\text { uczania w trybie } \\
\text { zdalnym }\end{array}$ & 20 & 6,9 & 75 & 25,8 & 127 & 43,6 & 42 & 14,4 & 19 & 6,5 & 8 & 2,7 \\
\hline $\begin{array}{l}\text { Umiejętności } \\
\text { zdobyte podczas } \\
\text { nauczania } \\
\text { w trybie zdal- } \\
\text { nym }\end{array}$ & 22 & 7,6 & 65 & 22,3 & 116 & 39,9 & 47 & 16,2 & 33 & 11,3 & 8 & 2,7 \\
\hline $\begin{array}{l}\text { Kompetencje } \\
\text { zdobyte podczas } \\
\text { nauczania } \\
\text { w trybie zdal- } \\
\text { nym }\end{array}$ & 13 & 4,5 & 64 & 22,0 & 136 & 46,7 & 39 & 13,4 & 26 & 8,9 & 13 & 4,5 \\
\hline $\begin{array}{l}\text { Przygotowanie } \\
\text { prowadzących } \\
\text { zajęcia do pracy } \\
\text { w systemie } \\
\text { zdalnym }\end{array}$ & 24 & 8,2 & 67 & 23,0 & 118 & 40,5 & 46 & 15,8 & 23 & 7,9 & 13 & 4,5 \\
\hline $\begin{array}{l}\text { Przygotowa- } \\
\text { nie uczelni do } \\
\text { nauki w trybie } \\
\text { zdalnym }\end{array}$ & 26 & 8,9 & 58 & 19,9 & 116 & 39,9 & 53 & 18,2 & 25 & 8,6 & 13 & 4,5 \\
\hline $\begin{array}{l}\text { Własna moty- } \\
\text { wacja do nauki } \\
\text { podczas zajęć } \\
\text { zdalnych }\end{array}$ & 31 & 10,7 & 67 & 23,0 & 85 & 29,2 & 50 & 17,2 & 52 & 17,9 & 6 & 2,1 \\
\hline $\begin{array}{l}\text { Obieg doku- } \\
\text { mentów na } \\
\text { uczelni }\end{array}$ & 14 & 4,8 & 73 & 25,1 & 108 & 37,1 & 46 & 15,8 & 27 & 9,3 & 23 & 7,9 \\
\hline
\end{tabular}




\begin{tabular}{|l|r|r|r|r|r|r|r|r|r|r|r|r|}
\hline $\begin{array}{l}\text { Kontakt } \\
\mathrm{z} \text { dziekanatem }\end{array}$ & 28 & 9,6 & 73 & 25,1 & 80 & 27,5 & 46 & 15,8 & 34 & 11,7 & 30 & 10,3 \\
\hline $\begin{array}{l}\text { Kontakt z pro- } \\
\text { wadzącymi } \\
\text { zajęcia }\end{array}$ & 28 & 9,6 & 118 & 40,5 & 86 & 29,6 & 36 & 12,4 & 11 & 3,8 & 12 & 4,1 \\
\hline $\begin{array}{l}\text { Kontakt z Biu- } \\
\text { rem Obsługi } \\
\text { Osób Niepełno- } \\
\text { sprawnych }\end{array}$ & 63 & 21,6 & 66 & 22,7 & 48 & 16,5 & 23 & 7,9 & 11 & 3,8 & 80 & 27,5 \\
\hline $\begin{array}{l}\text { Kontakt z prze- } \\
\text { wodniczącym } \\
\text { roku / starostą }\end{array}$ & 55 & 18,9 & 88 & 30,2 & 64 & 22,0 & 15 & 5,2 & 17 & 5,8 & 52 & 17,9 \\
\hline $\begin{array}{l}\text { Kontakt z inny- } \\
\text { mi studentami }\end{array}$ & 86 & 29,6 & 79 & 27,1 & 69 & 23,7 & 26 & 8,9 & 21 & 7,2 & 10 & 3,4 \\
\hline
\end{tabular}

Źródło: opracowanie własne.

\section{OBSZAR SPOŁECZNO-PSYCHOLOGICZNY ZWIĄZANY ZE ZDALNĄ EDUKACJĄ}

W ocenie obszarów, na które wpływ miała pandemia i konieczność zdalnej nauki, wskazywano przede wszystkim wpływ negatywny. Odpowiedź negatywna jest najczęściej wybieraną dla wszystkich aspektów, z wyjątkiem relacji rodzinnych. Dla samopoczucia odsetek takich odpowiedzi stanowi 36,4\% (106 osób), relacji koleżeńskich - 34,7\% (101 osób), zdrowia psychicznego i codziennego funkcjonowania po 33,3\% (97 osób), zdrowia fizycznego - 30,9\% (90 osób). Na drugim miejscu pod względem częstości występowania znalazły się odpowiedzi „pozytywnie”, w przypadku relacji rodzinnych był to nawet odsetek relatywnie najwyższy - 34,0\% (99 osób). Pozytywny wpływ na codzienne funkcjonowanie wskazało 66 respondentów, co stanowi 22,7\% udziału odpowiedzi na to pytanie, odsetek przewyższający nieco 20,0\% odnotowano również dla zdrowia fizycznego i samopoczucia - odpowiednio 20,6\% (60 osób) i 20,3\% (59 osób), odsetek 19,9\% odpowiedzi w danej kategorii (wskazania 58 osób) wystąpiło dla jakości życia, pozytywny wpływ zdalnego nauczenia dla zdrowia psychicznego wskazało 49 osób, co stanowi 16,8\%, w zakresie relacji koleżeńskich - 17,9\% (52 osoby). Biorąc pod uwagę sumę odpowiedzi „negatywnie” i „bardzo negatywnie” versus sumę odpowiedzi „pozytywnie” i „bardzo pozytywnie”, to tych pierwszych jest o ponad 1/3 więcej. Można więc przyjąć, iż pandemia wpłynęła negatywnie na wszystkie aspekty funkcjonowania, poza życiem rodzinnym, uczestniczących w badaniu studentów z niepełnosprawnościami. 
Tabela 7. Proszę o ocenę tego, w jaki sposób pandemia i konieczność zdalnej nauki wpłynęła na następujące obszary $(\mathrm{N}=291, \mathrm{w} \%)$

\begin{tabular}{|c|c|c|c|c|c|c|c|c|c|c|c|c|}
\hline & \multicolumn{2}{|c|}{$\begin{array}{c}\text { Bardzo } \\
\text { pozytyw- } \\
\text { nie }\end{array}$} & \multicolumn{2}{|c|}{$\begin{array}{l}\text { Pozytyw- } \\
\text { nie }\end{array}$} & \multicolumn{2}{|c|}{$\begin{array}{l}\text { Negatyw- } \\
\text { nie }\end{array}$} & \multicolumn{2}{|c|}{$\begin{array}{c}\text { Bardzo } \\
\text { negatyw- } \\
\text { nie }\end{array}$} & \multicolumn{2}{|c|}{$\begin{array}{c}\text { Nie } \\
\text { wpłynęło }\end{array}$} & \multicolumn{2}{|c|}{$\begin{array}{l}\text { Nie wiem } \\
\text { / trudno } \\
\text { powie- } \\
\text { dzieć }\end{array}$} \\
\hline & $\mathbf{N}$ & $\%$ & $\mathbf{N}$ & $\%$ & $\mathbf{N}$ & $\%$ & $\mathbf{N}$ & $\%$ & $\mathbf{N}$ & $\%$ & $\mathbf{N}$ & $\%$ \\
\hline $\begin{array}{l}\text { W zakresie } \\
\text { Pani/Pana } \\
\text { zdrowia } \\
\text { fizycznego }\end{array}$ & 21 & 7,2 & 60 & 20,6 & 90 & 30,9 & 38 & 13,1 & 61 & 21,0 & 21 & 7,2 \\
\hline $\begin{array}{l}\text { W zakresie } \\
\text { Pani/Pana } \\
\text { zdrowia } \\
\text { psychicznego }\end{array}$ & 17 & 5,8 & 49 & 16,8 & 97 & 33,3 & 61 & 21,0 & 45 & 15,5 & 22 & 7,6 \\
\hline $\begin{array}{l}\text { W zakresie } \\
\text { codziennego } \\
\text { funkcjonowania }\end{array}$ & 21 & 7,2 & 66 & 22,7 & 97 & 33,3 & 38 & 13,1 & 42 & 14,4 & 27 & 9,3 \\
\hline $\begin{array}{l}\text { W zakresie } \\
\text { jakości życia }\end{array}$ & 15 & 5,2 & 58 & 19,9 & 95 & 32,6 & 39 & 13,4 & 52 & 17,9 & 32 & 11,0 \\
\hline $\begin{array}{l}\text { W zakresie } \\
\text { Pani/Pana } \\
\text { samopoczucia }\end{array}$ & 16 & 5,5 & 59 & 20,3 & 106 & 36,4 & 56 & 19,2 & 31 & 10,7 & 23 & 7,9 \\
\hline $\begin{array}{l}\text { W zakresie } \\
\text { relacji } \\
\text { rodzinnych }\end{array}$ & 28 & 9,6 & 99 & 34,0 & 43 & 14,8 & 23 & 7,9 & 78 & 26,8 & 20 & 6,9 \\
\hline $\begin{array}{l}\text { W zakresie } \\
\text { relacji koleżeń- } \\
\text { skich (pozaro- } \\
\text { dzinnych) }\end{array}$ & 17 & 5,8 & 52 & 17,9 & 101 & 34,7 & 45 & 15,5 & 58 & 19,9 & 18 & 6,2 \\
\hline
\end{tabular}

Źródło: opracowanie własne.

Studenci, poproszeni o wyrażenie swojej opinii na temat konieczności przejścia na zdalne nauczanie, odpowiadali na pytania dotyczące następujących kwestii:

- Możliwość zdobycia nowych kompetencji - relatywnie najwyższy odsetek raczej się zgadza z tym stwierdzeniem, jest to $27,8 \%$ (81 osób), 26,8\% (78 osób) nie ma zdania, 25,1\% (73 osoby) raczej się nie zgadza, 10,7\% (31 osób) zdecydowanie się nie zgadza, 9,6\% (28 osób) zdecydowanie się zgadza.

- „Muszę radzić sobie ze wszystkim sama/sam” - raczej zgadza się z tym stwierdzeniem 39,9\% studentów (116 osób), zdecydowanie zgadza się 18,2\% (53 oso- 
by), 17,2\% (50 osób) nie ma zdania, 16,2\% (47 osób) raczej się nie zgadza i 8,6\% (25 osób) zdecydowanie się nie zgadza.

- Uczenie się nowych technologii dla 36,4\% (106 osób) jest stwierdzeniem, z którym raczej się zgadzają, 21,6\% (63 osoby) nie mają zdania na ten temat lub raczej się nie zgadzają, 14,8\% (43 osoby) zdecydowanie się zgadza, 5,5\% (16 osób) zdecydowanie się nie zgadza.

- „Stresuję się nową sytuacją” jest stwierdzeniem, z którym raczej zgadza się 35,4\% (103 osoby), 20,6\% (60 osób) raczej się nie zgadza, 18,6\% (54 osoby) nie ma zdania, $17,9 \%$ (52 osoby) zdecydowanie się zgadza i 7,6\% (22 osoby) zdecydowanie się nie zgadzają.

- „Uczę się zarządzać czasem” - z tym stwierdzeniem raczej zgadza się 38,8\% (113 osób), 22,0\% (64 osoby) nie ma zdania, 18,2\% (53 osoby) raczej nie zgadzają się, 11,7\% (34 osoby) zdecydowanie się zgadzają, 9,3\% (27 osób) zdecydowanie się nie zgadza.

- „Mam poczucie osamotnienia” - raczej zgadza się z tym zdaniem 32,6\% (95 osób), raczej się nie zgadza 22,7\% (66 osób), 18,6\% (54 osoby) zdecydowanie się zgadzają, $17,9 \%$ (52 osoby) nie mają zdania, 8,2\% (24 osoby) zdecydowanie się nie zgadzają.

- „Mam więcej czasu dla siebie” - 33,3\% (97 osób) raczej zgadza się z tym, że ma więcej czasu, 19,9\% (58 osób) zdecydowanie się zgadza, 18,2\% (53 osoby) nie mają zdania na ten temat, $14,4 \%$ (42 osoby) zdecydowanie się nie zgadza i niemal taki sam odsetek 14,1\% (41 osób) raczej się nie zgadza.

- „Stresuję się bardziej brakiem czasu” - odpowiedzi dotyczące tego stwierdzenia rozkładają się dość równomiernie; 27,5\% (80 osób) odpowiedziało, że raczej się nie zgadza, następnie 26,1\% (76 osób) nie ma zdania na ten temat, 20,6\% (60 osób) raczej się zgadza, zdecydowanie nie zgadza się 15,8\% studentów (46 osób), zdecydowanie zgadza się 10,0\% (29 osób).

- „Mogę łączyć życie prywatne z edukacją” - 32,3\% (94 osoby) raczej zgadza się, że może łączyć życie prywatne z edukacją, 24,7\% (72 osoby) nie ma zdania, 19,6\% (57 osób) raczej się nie zgadza, 13,4\% (39 osób) zdecydowanie się zgadza i 10,0\% (29 osób) zdecydowanie nie zgadza się.

- „Obowiązki domowe utrudniają mi naukę” - 31,6\% (92 osoby) raczej nie zgadzają się z tym stwierdzeniem, 24,1\% (70 osób) nie ma zdania, 18,9\% (55 osoby) raczej się zgadza, zdecydowanie się nie zgadza 14,1\% (41 osób) i zdecydowanie zgadza się $11,3 \%$ (33 osoby).

- „Warunki domowe nie sprzyjają nauce” - odpowiedzi na to stwierdzenie rozkładają się dość równomiernie - 27,5\% (80 osób) raczej się nie zgadza, po 20,3\% (59 osób) zdecydowanie się nie zgadza i nie ma zdania, 18,9\% (55 osób) raczej się zgadza, 13,1\% (38 osób) zdecydowanie zgadza się, że warunki domowe nie sprzyjają nauce.

- „Zwiększyła się moja samodzielność w wykonywaniu zadań” - 35,7\% (104 osoby) nie mają zdania na ten temat, 33,0\% (96 osób) raczej się zgadzają, 14,1\% (41 osób) raczej się nie zgadzają, 10,3\% (30 osób) zdecydowanie się zgadza, 6,9\% (20 osób) uważa, że zdecydowanie nie zwiększyła się ich samodzielność w wykonywaniu zadań. 
- „Przez naukę zdalną nie mam czasu na życie prywatne” - 29,9\% (87 osób) raczej nie zgadza się, że nauka zdalna spowodowała brak czasu na życie prywatne, $27,5 \%$ (80 osób) nie ma zdania, 18,6\% (54 osoby) raczej zgadza się z tym stwierdzeniem, niemal tyle samo $18,2 \%$ (53 osoby) zdecydowanie się nie zgadzają, 5,8\% (17 osób) zdecydowanie się zgadza.

- „Przez naukę zdalną nie mam czasu na inne zajęcia poza nauką” - 30,6\% (89 osób) raczej nie zgadza się z tym stwierdzeniem, 24,7\% (72 osoby) nie ma zdania, 18,2\% (53 osoby) raczej się zgadza, 17,5\% (51 osób) zdecydowanie się nie zgadza, 8,9\% (26 osób) zdecydowanie się nie zgadza, że przez naukę zdalną brak im czasu na inne zajęcia.

- „Mam kontrolę nad planem dnia” - 35,7\% (104 osoby) raczej zgadzają się z tym stwierdzeniem, 24,1\% (70 osób) nie ma zdania, 21,3\% (62 osoby) raczej się nie zgadzają, 11,3\% (33 osoby) zdecydowanie się zgadzają, 7,6\% (22 osoby) zdecydowanie się nie zgadzają, że mają kontrolę nad planem dnia.

- „Nie mam czasu na pracę zawodową” - 35,4\% (103 osoby) nie mają zdania na temat braku czasu na pracę zawodową z powodu zdalnego nauczania, 26,8\% (78 osób) raczej się nie zgadza, 18,2\% (53 osoby) raczej się zgadza, 10,3\% (30 osób) zdecydowanie się nie zgadza, 9,3\% (27 osób) zdecydowanie się zgadza.

- „Brakuje mi koleżanek i kolegów z uczelni” - 34,4\% (100 osób) zdecydowanie zgadza się z tym stwierdzeniem, niemal tyle samo 34,0\% (99 osób) raczej zgadza się, że brakuje im koleżanek i kolegów z uczelni, 15,5\% (45osób) nie ma zdania, 8,6\% (25 osób) raczej się nie zgadza, a 7,6\% (22 osoby) zdecydowanie nie zgadzają się.

- „Brakuje mi kontaktów z wykładowcami” - 35,7\% (104 osoby) raczej zgadzają się z tym stwierdzeniem, 24,1\% (70 osób) zdecydowanie się zgadza, 20,3\% (59 osób) nie ma zdania, 12,0\% (35 osób) raczej się nie zgadza, 7,9\% (23 osoby) zdecydowanie się nie zgadza, że brakuje im kontaktów z wykładowcami.

- „Brakuje mi kontaktów z innymi pracownikami uczelni” - 31,3\% (91osób) raczej się z tym zgadza, 27,5\% ( 80 osób) nie ma zdania, 18,6\% (54 osoby raczej się nie zgadzają), 13,7\% (40 osób) zdecydowanie się zgadza, 8,9\% (26 osób) zdecydowanie się nie zgadza.

- „Brakuje mi spotkań towarzyskich, odbywających się po zajęciach” - 33,7\% (98 osób) raczej zgadza się z tym stwierdzeniem, 32,3\% (94 osoby) zdecydowanie się zgadzają, 18,6\% (54 osoby) nie mają zdania, 8,6\% (25 osób) zdecydowanie się nie zgadza, 6,9\% (20 osób) raczej się nie zgadza.

- „Moje relacje interpersonalne są lepsze niż przed pandemią” - 34,7\% (101 osób) nie ma zdania, 25,8\% (75 osób), zdecydowanie się nie zgadza, $25,1 \%$ (73 osoby) raczej się nie zgadzają, że ich relacje interpersonalne są lepsze przed pandemią. Z tym twierdzeniem raczej zgadza się 8,9\% (26 osób), natomiast 5,5\% (16) zdecydowanie się zgadza.

Podsumowując, ankietowani studenci najbardziej zdecydowanie wyrażają opinię, że „Muszą radzić sobie ze wszystkim sami” - twierdzi tak 40,0\% (116 osób). Jest to relatywnie najwyższy odsetek na tle wszystkich odpowiedzi. Na podobnym poziomie 39,0\% 
(113 osób) znalazła się opinia „Uczę się zarządzać czasem”. Uczestnicy badania najczęściej udzielali odpowiedzi „raczej się zgadzam”, a następnie „nie mam zdania”. Analiza odpowiedzi pokazuje również, że najbardziej ucierpiały kontakty społeczne, wskazują na to wysokie wyniki w zakresie odpowiedzi „zdecydowanie się zgadzam” i „raczej się zgadzam” na stwierdzenia: „Brakuje mi koleżanek i kolegów z uczelni”, „Brakuje mi kontaktów z wykładowcami”, „Brakuje mi spotkań towarzyskich odbywających się po zajęciach” oraz odpowiedzi „zdecydowanie się nie zgadzam” i „raczej się nie zgadzam” dla stwierdzenia „Moje relacje interpersonalne są lepsze, niż przed pandemią”. Opisane w tym akapicie wyniki znajdują się w tabeli 8 .

Tabela 8. Proszę o opinie i oceny związane z koniecznością przejścia na zdalne nauczanie w okresie pandemii $(\mathrm{N}=291$, w \%)

\begin{tabular}{|c|c|c|c|c|c|c|c|c|c|c|}
\hline & \multicolumn{2}{|c|}{$\begin{array}{c}\text { Zdecydo- } \\
\text { wanie się } \\
\text { nie zgadzam }\end{array}$} & \multicolumn{2}{|c|}{$\begin{array}{c}\text { Raczej się } \\
\text { nie zgadzam }\end{array}$} & \multicolumn{2}{|c|}{$\begin{array}{l}\text { Nie mam } \\
\text { zdania }\end{array}$} & \multicolumn{2}{|c|}{$\begin{array}{l}\text { Raczej się } \\
\text { zgadzam }\end{array}$} & \multicolumn{2}{|c|}{$\begin{array}{l}\text { Zdecydo- } \\
\text { wanie się } \\
\text { zgadzam }\end{array}$} \\
\hline & $\mathbf{N}$ & $\%$ & $\mathbf{N}$ & $\%$ & $\mathbf{N}$ & $\%$ & $\mathbf{N}$ & $\%$ & $\mathbf{N}$ & $\%$ \\
\hline $\begin{array}{l}\text { Mogę zdobyć } \\
\text { nowe kompetencje }\end{array}$ & 31 & 10,7 & 73 & 25,1 & 78 & 26,8 & 81 & 27,8 & 28 & 9,6 \\
\hline $\begin{array}{l}\text { Muszę radzić } \\
\text { sobie ze } \\
\text { wszystkim sama/ } \\
\text { sam }\end{array}$ & 25 & 8,6 & 47 & 16,2 & 50 & 17,2 & 116 & 39,9 & 53 & 18,2 \\
\hline $\begin{array}{l}\text { Uczę się nowych } \\
\text { technologii }\end{array}$ & 16 & 5,5 & 63 & 21,6 & 63 & 21,6 & 106 & 36,4 & 43 & 14,8 \\
\hline $\begin{array}{l}\text { Stresuję się nową } \\
\text { sytuacją }\end{array}$ & 22 & 7,6 & 60 & 20,6 & 54 & 18,6 & 103 & 35,4 & 52 & 17,9 \\
\hline $\begin{array}{l}\text { Uczę się zarządzać } \\
\text { czasem }\end{array}$ & 27 & 9,3 & 53 & 18,2 & 64 & 22,0 & 113 & 38,8 & 34 & 11,7 \\
\hline $\begin{array}{l}\text { Mam poczucie } \\
\text { osamotnienia }\end{array}$ & 24 & 8,2 & 66 & 22,7 & 52 & 17,9 & 95 & 32,6 & 54 & 18,6 \\
\hline $\begin{array}{l}\text { Mam więcej czasu } \\
\text { dla siebie }\end{array}$ & 42 & 14,4 & 41 & 14,1 & 53 & 18,2 & 97 & 33,3 & 58 & 19,9 \\
\hline $\begin{array}{l}\text { Stresuję się } \\
\text { brakiem czasu }\end{array}$ & 46 & 15,8 & 80 & 27,5 & 76 & 26,1 & 60 & 20,6 & 29 & 10,0 \\
\hline $\begin{array}{l}\text { Mogę łączyć } \\
\text { życie prywatne } \\
\text { z edukacją }\end{array}$ & 29 & 10,0 & 57 & 19,6 & 72 & 24,7 & 94 & 32,3 & 39 & 13,4 \\
\hline $\begin{array}{l}\text { Obowiązki domo- } \\
\text { we utrudniają mi } \\
\text { naukę }\end{array}$ & 41 & 14,1 & 92 & 31,6 & 70 & 24,1 & 55 & 18,9 & 33 & 11,3 \\
\hline
\end{tabular}




\begin{tabular}{|c|c|c|c|c|c|c|c|c|c|c|}
\hline $\begin{array}{l}\text { Warunki domowe } \\
\text { nie sprzyjają } \\
\text { nauce }\end{array}$ & 59 & 20,3 & 80 & 27,5 & 59 & 20,3 & 55 & 18,9 & 38 & 13,1 \\
\hline $\begin{array}{l}\text { Zwiększyła się } \\
\text { moja samodziel- } \\
\text { ność w wykony- } \\
\text { waniu zadań }\end{array}$ & 20 & 6,9 & 41 & 14,1 & 104 & 35,7 & 96 & 33,0 & 30 & 10,3 \\
\hline $\begin{array}{l}\text { Przez naukę } \\
\text { zdalną nie mam } \\
\text { czasu na życie } \\
\text { prywatne }\end{array}$ & 53 & 18,2 & 87 & 29,9 & 80 & 27,5 & 54 & 18,6 & 17 & 5,8 \\
\hline $\begin{array}{l}\text { Przez naukę } \\
\text { zdalną nie mam } \\
\text { czasu na inne } \\
\text { zajęcia poza nauką }\end{array}$ & 51 & 17,5 & 89 & 30,6 & 72 & 24,7 & 53 & 18,2 & 26 & 8,9 \\
\hline $\begin{array}{l}\text { Mam kontrolę nad } \\
\text { planem dnia }\end{array}$ & 22 & 7,6 & 62 & 21,3 & 70 & 24,1 & 104 & 35,7 & 33 & 11,3 \\
\hline $\begin{array}{l}\text { Nie mam czasu na } \\
\text { pracę zawodową }\end{array}$ & 30 & 10,3 & 78 & 26,8 & 103 & 35,4 & 53 & 18,2 & 27 & 9,3 \\
\hline $\begin{array}{l}\text { Brakuje mi kole- } \\
\text { żanek i kolegów } \\
\text { z uczelni }\end{array}$ & 22 & 7,6 & 25 & 8,6 & 45 & 15,5 & 99 & 34,0 & 100 & 34,4 \\
\hline $\begin{array}{l}\text { Brakuje mi } \\
\text { kontaktów } \\
\text { z wykładowcami }\end{array}$ & 23 & 7,9 & 35 & 12,0 & 59 & 20,3 & 104 & 35,7 & 70 & 24,1 \\
\hline $\begin{array}{l}\text { Brakuje mi kon- } \\
\text { taktów z innymi } \\
\text { pracownikami } \\
\text { uczelni }\end{array}$ & 26 & 8,9 & 54 & 18,6 & 80 & 27,5 & 91 & 31,3 & 40 & 13,7 \\
\hline $\begin{array}{l}\text { Brakuje mi spo- } \\
\text { tkań towarzyskich } \\
\text { odbywających się } \\
\text { po zajęciach }\end{array}$ & 25 & 8,6 & 20 & 6,9 & 54 & 18,6 & 98 & 33,7 & 94 & 32,3 \\
\hline $\begin{array}{l}\text { Moje relacje } \\
\text { interpersonalne są } \\
\text { lepsze niż przed } \\
\text { pandemią }\end{array}$ & 75 & 25,8 & 73 & 25,1 & 101 & 34,7 & 26 & 8,9 & 16 & 5,5 \\
\hline
\end{tabular}

Źródło: opracowanie własne. 
Odpowiedzi na pytanie o wsparcie uczelni w zdalnej nauce dzielą badaną zbiorowość na dwie niemal równe części, minimalnie większy odsetek 50,5\% (147 osób) wsparcie to otrzymało, w grę wchodzi jednak różnica tylko 3 osób. Wyniki zaprezentowano w tabeli 9 .

Tabela 9. Czy podczas nauki w systemie zdalnym otrzymał(a) Pani/Pan wsparcie ze strony uczelni? $(\mathrm{N}=291, \mathrm{w} \%)$

\begin{tabular}{|l|r|r|}
\hline Odpowiedź & $\mathbf{N}$ & $\mathbf{\%}$ \\
\hline Tak & 147 & 50,5 \\
\hline Nie & 144 & 49,5 \\
\hline Suma & 291 & 100,0 \\
\hline
\end{tabular}

Źródło: opracowanie własne.

Studenci, którzy otrzymali wsparcie ze strony uczelni (147 osób), wskazali zakres udzielonej pomocy. Badani wymieniali: adaptację materiałów 50,3\% (74 osoby), wsparcie informatyczne 44,2\% (65 osób), pomoc psychologiczną 18,4\% (27 osób), inne rodzaje wsparcia, takie jak: zapomoga finansowa, pakiet MS Office 365, pomoc koordynatora BON, stypendium dla osób niepełnosprawnych, konsultacje, pomoc w załatwianiu indywidualnej organizacji studiów, stypendium wskazało 12,2\% (18 osób), sprzęt 9,5\% (14 osób). Dane obrazuje tabela 10.

Tabela 10. Jakie wsparcie otrzymał(a) Pani/Pan ze strony Uczelni? (N=147, w \%)

\begin{tabular}{|l|r|r|}
\hline Odpowiedź & $\mathbf{N}$ & \% \\
\hline adaptacja materiałów & 74 & 50,3 \\
\hline wsparcie informatyczne & 65 & 44,2 \\
\hline pomoc psychologiczna & 27 & 18,4 \\
\hline inne wsparcie & 18 & 12,2 \\
\hline sprzęt & 14 & 9,5 \\
\hline
\end{tabular}

Źródło: opracowanie własne.

Uczestników badania zapytano także o oczekiwane wsparcie, którego brakuje podczas zdalnej edukacji w sytuacji pandemii COVID-19. Odpowiedzi badanych miały charakter otwarty, każdy z respondentów mógł przekazać dowolną, nieskrępowaną informację na ten temat. Odpowiedzi badanych były grupowane do szerszych kategorii, które przedstawione zostały w tabeli 11 . Na pytanie o potrzebną pomoc blisko co czwarta badana 
osoba nie miała zdania na ten temat, nie potrafiła sprecyzować i określić oczekiwanej pomocy. Część badanych - 15,8\% nie potrzebuje dodatkowego wsparcia. Pomocy finansowej na zakup sprzętu do nauki oraz na inne opłaty związane z edukacją oczekuje 12,0\% badanych studentów. Warto zauważyć, iż 6,9\% studentów z różnego rodzaju niepełnosprawnościami oczekuje w dobie zdalnego kształcenia także wsparcia psychologicznego, pomocy mentalnej. 6,5\% badanych postulowało pełniejszy i dłuższy dostęp do materiałów naukowych (wykładów, ćwiczeń, opracowań, notatek itp.) - archiwizowanie takich materiałów z możliwością późniejszego dostępu. Badani oczekują także: usprawnienia przepływu informacji pomiędzy uczelnią a studentami, planowanie zajęć z wyprzedzeniem - 5,8\% wskazań, zwiększenia liczby indywidualnych godzin przyjęć, więcej czasu dostępności wykładowców oraz osób prowadzących zajęcia, ćwiczenia, konserwatoria, większe wsparcie dydaktyczne - 4,1\% wskazań, większej wyrozumiałości wykładowców - 4,1\% oraz pomocy doraźnej, bieżącej w rozwiązywaniu problemów technicznych związanych z nauczaniem zdalnym - 3,4\% wskazań. Pozostałe potrzeby i oczekiwania studentów związane z kształceniem zdalnym przedstawione zostały w tabeli 11 .

Tabela 11. Oczekiwane wsparcie w czasie zdalnej nauki $(\mathrm{N}=291$, w \%)

\begin{tabular}{|l|r|r|}
\hline Oczekiwane wsparcie & $\mathbf{N}$ & $\%$ \\
\hline Nie wiem / Nie mam zdania & 70 & 24,1 \\
\hline Nie potrzebuję wsparcia & 46 & 15,8 \\
\hline Wsparcie finansowe: zakup sprzętu do nauki, opłaty za rachunki & 35 & 12,0 \\
\hline Pomoc/wsparcie psychologa & 20 & 6,9 \\
\hline Dostęp do materiałów & 19 & 6,5 \\
\hline Lepszy przepływ informacji: administracja, planowanie zajęć & 17 & 5,8 \\
\hline $\begin{array}{l}\text { Więcej indywidualnych godzin przyjęć/ czasu wykładowców/wsparcie } \\
\text { dydaktyczne }\end{array}$ & 12 & 4,1 \\
\hline Dobre słowo, wyrozumiałość wykładowców & 12 & 4,1 \\
\hline Pomoc doraźna w problemach technicznych & 10 & 3,4 \\
\hline Zajęcia w laboratoriach & 7 & 2,4 \\
\hline $\begin{array}{l}\text { Wsparcie merytoryczne, udzielanie odpowiedzi na pytania przez wy- } \\
\text { kładowców, dostępność wykładowców dla studentów }\end{array}$ & 7 & 2,4 \\
\hline Szkolenie z zarządzania czasem, obsługi Teams, zajęcia językowe & 6 & 2,1 \\
\hline Dobre przygotowanie prowadzących do zajęć w zakresie obsługi sprzętu & 5 & 1,7 \\
\hline Niższe opłaty za studia & 4 & 1,4 \\
\hline Nagrywanie wykładów, zajęć & 4 & 1,4 \\
\hline Możliwość korzystania z sali komputerowej, biblioteki & 3 & 1,0 \\
\hline Świadczenia socjalne & 3 & 1,0 \\
\hline Lepsze przygotowanie prowadzących, zajęcia w formie dyskusji & 3 & 1,0 \\
\hline Szybsze łącze internetowe & 3 & 1,0 \\
\hline
\end{tabular}




\begin{tabular}{|l|r|r|}
\hline Wsparcie w kontakcie z wykładowcą & 2 & 0,7 \\
\hline Zwiększona czas na wykonywanie prac & 1 & 0,3 \\
\hline Darmowy dostęp do internetu & 1 & 0,3 \\
\hline Wsparcie osób niepełnosprawnych & 1 & 0,3 \\
\hline
\end{tabular}

Źródło: opracowanie własne.

Odpowiedzi na pytania o chęć korzystania ze zdalnego nauczania w przyszłości wskazują na umiarkowanie pozytywne nastawienie badanych studentów z niepełnosprawnościami - 37,8\% (110 osób) wyraziło opinię „raczej tak” i jest to najliczniejsza podgrupa. Zdecydowanie chciałoby korzystać z e-learningu 19,6\% badanych (57 osób), raczej nie - 20,6\% (60 osób), zdecydowanie nie - 9,6\% (28 osób). Odpowiedzi „trudno powiedzieć” udzieliło 12,4\% (36 osób). Odpowiedzi pozytywnych jest w sumie 57,4\%, dla większości więc zdalne nauczanie okazało się doświadczeniem, które chcą w jakimś wymiarze kontynuować.

\section{POZYTYWNE ASPEKTY KSZTAŁCENIA NA ODLEGŁOŚĆ}

Uczestników badania - niepełnosprawnych studentów, zapytano o pozytywne aspekty związane z kształceniem zdalnym. Każdy z badanych poproszony został o wskazanie maksymalnie trzech odpowiedzi. Wypowiedzi badanych miały charakter otwarty - były swobodną wypowiedzią respondenta. Każda z odpowiedzi została w dalszym etapie skategoryzowana i przypisana do szerszych kategorii.

Zdaniem badanych najważniejszym pozytywnym aspektem zdalnego nauczania, wymienianym przez 39,2\% studentów, jest oszczędność czasu związana z brakiem konieczności dojazdu na uczelnię (zajęcia, wykłady, ćwiczenia). Niewątpliwie pozytywnym aspektem, który pojawił się w 34,4\% odpowiedzi, jest możliwość pracy w przyjaznym miejscu bez czynników stresujących - w domu. Dla wielu badanych studentów taka forma edukacji jest po prostu wygodna. Niepełnosprawni studenci wskazali także na lepszą organizację czasu. Taka forma edukacji sprawia, że respondenci mają więcej czasu zarówno na samą naukę, jak i więcej czasu dla siebie. Odpowiedzi o takiej konotacji wymieniło 32,0\% badanych. Zdalna edukacja zdaniem 19,2\% badanych powoduje lepszą organizację planu dnia, pracy oraz samej nauki. 15,1\% badanych zwróciło uwagę na taki pozytywny aspekt kształcenia zdalnego, jak minimalizacja ryzyka zarażenia w dobie pandemii Covid - 19. Taki sam odsetek badanych - 15,1\% zwrócił uwagę na redukcję kosztów związanych z edukacją. Pozytywnym skutkiem zdalnego nauczania jest ograniczenie wydatków, takich jak: koszty paliwa, biletów, parkingu, wynajmu mieszkania. Więcej niż co dziesiąty uczestnik badania $(11,3 \%)$ zwrócił uwagę na usamodzielnienie się jako efekt konieczności przejścia na zdalny system edukacji. Poznanie nowych narzędzi pracy zdalnej, obsługa internetu, programów i platform edukacyjnych jest kolejnym pozytywnym aspektem związanym z kształceniem zdalnym. Takie odpowiedzi wskazało 9,6\% badanych. 
$\mathrm{Na}$ istotny aspekt: „brak negatywnego odbioru osób niepełnosprawnych przez innych studentów" jako pozytywny wpływ zdalnej edukacji zwróciło uwagę 7,9\% badanych. Dla $7,2 \%$ badanych dobrą cechą kształcenia zdalnego jest lepsze samopoczucie. Na łatwiejszy dostęp do materiałów zwróciło uwagę $6,5 \%$ badanych, natomiast na możliwość ponownego odtworzenia materiału przesłanego przez wykładowców - 5,8\% niepełnosprawnych studentów. Pozostałe pozytywne opinie związane z edukacją zdalną przedstawione zostały w tabeli 12 .

Tabela 12. Pozytywne aspekty kształcenia zdalnego.

\begin{tabular}{|l|r|r|}
\hline Pozytywne aspekty & $\mathbf{N}$ & \% \\
\hline Oszczędność czasu na dojazdy & 114 & 39,2 \\
\hline $\begin{array}{l}\text { Praca w przyjaznym miejscu: bez czynników stresujących, w domu, } \\
\text { wygoda }\end{array}$ & 100 & 34,4 \\
\hline Więcej czasu na naukę/ dla siebie & 93 & 32,0 \\
\hline Lepsza organizacja dnia/pracy/nauki & 56 & 19,2 \\
\hline Mniejsze ryzyko zarażenia & 44 & 15,1 \\
\hline Redukcja wydatków: paliwo, bilety, parking, wynajem mieszkania & 44 & 15,1 \\
\hline Samodzielna praca & 33 & 11,3 \\
\hline $\begin{array}{l}\text { Używanie nowych narzędzi pracy: internet, MSTeams, platforma } \\
\text { edukacyjna }\end{array}$ & 28 & 9,6 \\
\hline Brak wyśmiewania przez kolegów/wykładowców & 23 & 7,9 \\
\hline Lepsze samopoczucie & 21 & 7,2 \\
\hline Łatwiejszy dostęp do materiałów & 19 & 6,5 \\
\hline $\begin{array}{l}\text { Przesyłanie przez prowadzących nagrań wykładów, notatek - } \\
\text { ponowne odtworzenie materiału }\end{array}$ & 17 & 5,8 \\
\hline Sprawniejsze rozwiązywanie problemów studentów & 15 & 5,2 \\
\hline Zaangażowanie w prowadzenie domu & 12 & 4,1 \\
\hline Mniejszy stres przy zaliczeniach & 12 & 4,1 \\
\hline Możliwość jedzenia w trakcie zajęć & 11 & 3,8 \\
\hline Lepsza jakość materiałów od wykładowców & 5 & 2,7 \\
\hline Dbałość o zdrowie swoje i innych & 5 & 1,7 \\
\hline Spotkania online ludzi z grupy & 1 & 1,4 \\
\hline Decydowanie o przerwie & 1 & 0,7 \\
\hline Możliwość innej pozycji niż siedząca (dla osoby niepełnosprawnej) & 0,3 \\
\hline Lepsze panowanie nad emocjami & 0,3 \\
\hline
\end{tabular}

Źródło: opracowanie własne. 
Kolejnym elementem diagnozy kształcenia zdalnego było wskazanie negatywnych aspektów, które wiązały się z koniecznością przejścia na taki system edukacji. Każdy z badanych studentów mógł wymienić trzy niekorzystne jego zdaniem elementy związane z kształceniem na odległość. Pojedyncze odpowiedzi respondentów przypisane zostały do szerszych kategorii, które zostały pogrupowane według liczebności wskazań. Blisko połowa badanych studentów zwróciła uwagę na brak bezpośredniego kontaktu z innymi studentami. Taki negatywny efekt zdalnej edukacji wskazało aż 48,8\% badanych. Ważnym problemem poruszonym przez $28,2 \%$ ankietowanych jest utrudniony kontakt $\mathrm{z}$ wykładowcami, brak możliwości kontaktu bezpośredniego z prowadzącymi zajęcia. Liczne opinie - 27,8\% dotyczyły także gorszego samopoczucia studentów, poczucia izolacji, braku ruchu, braku motywacji czy też brak możliwość skupienia. Pogorszenie wymienionych aspektów było efektem konieczności zdalnego nauczania. Istotną trudnością wynikającą z kształcenia zdalnego dla 24,7\% studentów z różnego rodzaju niepełnosprawnościami były problemy techniczne, problemy z jakością połączenia internetowego, problemy ze sprzętem dedykowanym do nauki zdalnej. Do negatywnych aspektów badani zaliczyli także niższy poziom nauczania w porównaniu do tradycyjnej (stacjonarnej) metody kształcenia - 13,7\% oraz brak zajęć praktycznych, np. laboratorium - 13,1\%. Taka forma edukacji przyczyniła się także do dezorganizacji dotychczasowego rytmu dnia, badani skarżyli się na gorszą organizację czasu nauki, czasu pracy, czasu obowiązków rodzinnych. W opinii $13,1 \%$ badanych zachwiana została równowaga pomiędzy życiem prywatnym a czasem związanym z nauką. Część badanych (7,6\%) uważa, że taka forma kształcenia jest mniej efektywna. W opinii 6,9\% badanych konieczność kształcenia zdalnego przyniosła następujące negatywne efekty: bóle pleców i głowy związane z długotrwałym siedzeniem przed komputerem, poprzez brak odpowiednich warunków do nauki. Studenci narzekali także na brak ciszy, spokoju oraz miejsca potrzebnego do nauki, konieczność przyswojenia jednorazowo większych partii materiału oraz utrudniony kontakt z dziekanatem (niezałatwianie spraw na czas). Pozostałe negatywne opinie dotyczące kształcenia zdalnego przedstawione zostały w tabeli 13.

Tabela 13. Negatywne aspekty kształcenia zdalnego

\begin{tabular}{|l|r|r|}
\hline Negatywne aspekty & $\mathbf{N}$ & $\mathbf{\%}$ \\
\hline Brak kontaktu ze studentami & 142 & 48,8 \\
\hline Utrudniony kontakt z wykładowcami/brak kontaktu bezpośredniego & 82 & 28,2 \\
\hline $\begin{array}{l}\text { Gorsze samopoczucie, izolacja, brak ruchu, brak motywacji, brak } \\
\text { skupienia }\end{array}$ & 81 & 27,8 \\
\hline Problemy techniczne: łącze, sprzęt, brak odpowiedniego sprzętu & 72 & 24,7 \\
\hline Niższy poziom nauczania & 40 & 13,7 \\
\hline Brak zajęć praktycznych: laboratorium & 38 & 13,1 \\
\hline
\end{tabular}




\begin{tabular}{|l|r|r|}
\hline Gorsza organizacja czasu nauki/pracy/ czasu & 38 & 13,1 \\
\hline Nauka zdalna przynosi mniejsze efekty & 22 & 7,6 \\
\hline Długotrwałe siedzenie przy komputerze: ból pleców, głowy & 20 & 6,9 \\
\hline Brak odpowiednich warunków: ciszy, spokoju, miejsca & 20 & 6,9 \\
\hline Realizacja większych partii materiału & 20 & 6,9 \\
\hline Utrudniony kontakt z dziekanatem/ niezałatwianie spraw na czas & 20 & 6,9 \\
\hline Opracowanie zadań jest czasochłonne & 16 & 5,5 \\
\hline Gorsze przygotowanie prowadzących do zajęć & 15 & 5,2 \\
\hline Brak regularnego trybu związanego z nauką & 15 & 5,2 \\
\hline Wysokie opłaty za studia/koszty z zakupem sprzętu & 7 & 2,4 \\
\hline Presja czasu na zaliczeniach/stres & 5 & 1,7 \\
\hline Unikanie zajęć & 5 & 1,7 \\
\hline Problem z oczami & 4 & 1,4 \\
\hline Egzaminy i zaliczenia w formie online & 4 & 1,4 \\
\hline Krytyka ze strony innych studentów & 1 & 0,3 \\
\hline Nauka języków obcych na niższym poziomie & 1 & 0,3 \\
\hline Trudności w znalezieniu praktyk w małym mieście & 1 & 0,3 \\
\hline Brak przerw & 1 & 0,3 \\
\hline
\end{tabular}

Źródło: opracowanie własne.

\section{PODSUMOWANIE}

Większość $(82,8 \%)$ studentów nie miało żadnych doświadczeń ze zdalnym nauczaniem przed pandemią, co oznacza, że ich pierwsze zetknięcie z kształceniem na odległość zostało im narzucone i wymuszone okolicznościami zewnętrznymi. Okoliczności te z pewnością wpłynęły na postawy uczestników badania wobec e-learningu. Spośród tych, którzy uczyli się zdalnie wcześniej, aż 60,0\% miała takie doświadczenie tylko ucząc się 1-2 przedmiotów. Należy również zauważyć, że ponad połowa uczestników zdalnego nauczania nie była z niego zadowolona. Sytuację wyjściową, w grupie studentów o specjalnych potrzebach edukacyjnych, przed rozpoczęciem pandemii można określić jako niekorzystną (por. Domagała-Zyśk, 2020). W tym kontekście wszelkie przejawy przychylności studentów i ich postępy można postrzegać w kategoriach sukcesu. Reakcja studentów na konieczność przejścia na zdalne nauczanie była raczej neutralna lub pozytywna. Wydaje się więc, że studenci, którzy nie spotkali się wcześniej z e-learningiem, nie przejawiali ani uprzedzeń, ani zbytniego entuzjazmu wobec tej formy nauczania. Odsetek studentów przygotowanych w dużym i średnim stopniu wynosi łącznie 62,2\%, co znacząco przekracza odsetek tych, którzy uczyli się zdalnie (17,2\%). Jest to samoocena przygotowania do nauki zdalnej, która wskazuje, że być może studenci mieli kursy wprowadzające do 
e-learningu na uczelni lub mają poczucie przygotowania, gdyż prywatnie korzystali ze zdalnej nauki na platformach lub też - być może - przeceniają swoje przygotowanie do tego typu zajęć.

Większość $(74,9 \%)$ studentów w związku z podjęciem zdalnej nauki nie zmieniła miejsca zamieszkania, co może być jednym z powodów względnie pozytywnego nastawienia do obowiązku zdalnego nauczania, pomimo umiarkowanych bądź żadnych wcześniejszych doświadczeń. Większość studentów deklaruje komfortowe warunki nauki zdalnej w domu, w oddzielnym pomieszczeniu - prawdopodobnie własny pokój (odsetki te przekraczają 80,0\%). Tylko 2,1\% uczyło się u znajomych lub w miejscu innym niż własny dom, akademik czy wynajęte mieszkanie - $0,7 \%$. Odsetki te, choć marginalne, wskazują na problemy ze znalezieniem miejsca do nauki przez niektórych studentów. Natomiast problemy z wymaganym sprzętem dotyczą mniejszości (17,5\%) studentów, a wśród koniecznych zakupów na pierwszym miejscu wskazano oprogramowanie, sprzęt komputerowy, następnie dostęp do internetu, a więc artykuły i usługi niezbędne w e-learningu, a nie jedynie wspomagające. Do zdalnej nauki studenci wykorzystują w pierwszej kolejności laptopy, natomiast zdecydowanie rzadko tablety.

W kolejnej części badania studentów pytano o sposób przeprowadzania zajęć na uczelni. W odpowiedziach przeważała forma zajęć online, polegająca na wykładzie "na żywo", natomiast niezmiernie rzadko wykładowcy udostępniają nagrane wykłady. Wykładowcy często udostępniają pliki prezentacji w formacie pdf lub PowerPoint oraz wysyłają materiały pocztą elektroniczną. Platformy e-learningowe są umiarkowanie często wykorzystywane, tylko 21,0\% wykładowców (zdaniem studentów) wykorzystuje je bardzo często, a 32,3\% często, co daje w sumie niewiele ponad połowę. Ocena pod kątem przydatności form zdalnej nauki wskazała w pierwszym rzędzie na wykład "na żywo", a następnie (umiarkowanie często wykorzystywaną) platformę e-learningowa. Nasuwa się więc wniosek, że prowadzący zajęcia nie do końca wychodzą naprzeciw oczekiwaniom studentów (por. Plichta, 2020).

Kolejna kwestia dotyczyła narzędzi wsparcia zajęć online. W opinii studentów wykładowcy w ograniczonym zakresie korzystają z tych narzędzi - dominuje MS Teams i e-mail, natomiast narzędzia takie jak Adobe Content, Cisco WebEx Meetings, czy ClickMeeting, Discord są praktycznie pomijane. Jako najbardziej przydatne studenci ocenili MS Teams i e-mail, następnie platformy e-learningowe. Rezultat ten jest jednak efektem nieznajomości innych narzędzi przez większość uczestników badania. W kwestionariuszu pojawiło się również pytanie o dodatkowe formy interakcji z nauczycielami prowadzącymi zajęcia - wykładowcy stawiają tu głównie na rozmowy online i komunikację za pomocą czatu.

Uczestnicy badania oceniają zajęcia jako raczej lub zdecydowanie dopasowane do ich szczególnych potrzeb edukacyjnych, tylko 4,4\% wskazuje na pewne problemy w tym zakresie. Zastanawiający jest dość wysoki $(22,0 \%)$ odsetek studentów z niepełnosprawnościami nieumiejących udzielić odpowiedzi na to pytanie. Porównując jakość zajęć zdalnych i stacjonarnych ankietowani studenci zdecydowanie stawiają na zajęcia $\mathrm{w}$ formie tradycyjnej, w szczególności dotyczy to laboratoriów, praktyk i ćwiczeń, stosunkowo dobrze tolerując wykłady w formie zdalnej. W ocenie wybranych aspektów zdalnej nauki uczestnicy badania w zdecydowanej większości wydali oceny przeciętne, wysoko ocenili jedynie kontakty 
z wykładowcami na uczelni. Studenci uczestniczący w badaniu w większości zdają egzaminy i zaliczenia w formie zdalnej i blisko 40,0\% skarży się na problemy w ich trakcie.

Pytanie o wpływ zdalnego nauczania i pandemii na funkcjonowanie poza uczelnią ujawniło, że niemal we wszystkich aspektach (z wyjątkiem życia rodzinnego) wpływ tych zjawisk był negatywny. Respondenci zadeklarowali, że zdalne nauczenie źle wpłynęło na ich zdrowie fizyczne i psychiczne, ale też codzienne funkcjonowanie, jakość życia, ogólne samopoczucie i relacje koleżeńskie. Konieczność przejścia na e-edukację w opinii badanych studentów z niepełnosprawnościami przyniosło ze sobą przymus samodzielnego radzenia sobie ze wszystkimi problemami, jakie pojawiły się w związku z nową sytuacją (40,0\% badanych). Zauważają oni również dotkliwy brak kontaktów społecznych zarówno z kolegami, jak i wykładowcami, ogólnie ubóstwo życia towarzyskiego oraz pogorszenie relacji interpersonalnych. Należy jednak zaznaczyć, że połowa uczestników badania przyznaje, że uzyskało wsparcie uczelni w zdalnym nauczaniu. W największej mierze wsparcie to dotyczyło adaptacji materiałów i pomocy informatycznej, a w najmniejszym stopniu niezbędnego sprzętu. Pokazuje to, że młodzi ludzie, w tym również, a może przede wszystkim osoby z niepełnosprawnościami, są wyposażone w sprzęt typu komputer, laptop, smartfon itp., a adaptacja materiałów jest w ofercie wielu uczelnianych jednostek wspierających studentów z niepełnosprawnościami i nie zmieniła tego pandemia. Natomiast można przypuszczać, że zdalne nauczanie spotęgowało konieczność adaptacji materiałów dla studentów z konkretnymi dysfunkcjami.

Warto podkreślić, że po kilku miesiącach zdalnego nauczania studenci wykazują umiarkowanie pozytywne nastawienie wobec tego rodzaju nauki, raczej lub zdecydowanie chce z niego korzystać 57,4\%, a zdecydowanie niechętnych jest jedynie 9,6\%. Biorąc pod uwagę, że zdecydowana większość z nich nie miała wcześniej doświadczeń z e-learningiem, można uznać, że jest to dobry wynik i wielu studentów przekonało się do zdalnego nauczania.

Na podstawie raportu można zarekomendować większe wsparcie ze strony uczelni - studenci proponowali urozmaicenie form, sposobów realizacji zajęć dydaktycznych, inicjowania interakcji społecznych w ramach zajęć, lepszą komunikację między wykładowcami i studentami, jak i komunikację w gronie studentów (por. Gulati, 2020). Niezbędne wydaje się także przeszkolenie wykładowców z zakresie świadomości niepełnosprawności i specjalnych potrzeb edukacyjnych wśród studentów, tak by oferowane zajęcia zdalne były lepiej dopasowane do ich możliwości i potrzeb. Połączenie wiedzy metodycznej z zakresu e-learningu ze świadomością potrzeb studentów z niepełnosprawnościami pozwoli zapewne zniwelować część dodatkowych barier (poza czysto technicznymi), na które zwracają uwagę badani studenci. Narzędzia cyfrowe, w tym cały czas rozwijające się platformy zdalnej edukacji (również pod kątem dostępności dla osób o szczególnych potrzebach), wydają się być dużą szansą na efektywne nauczanie studentów z niepełnosprawnościami, a w konsekwencji zwiększenie dostępu do edukacji akademickiej dla tej, niejednokrotnie wykluczonej, grupy społecznej.

Wydaje się, że wnioski z powyższego raportu mogą być przyczynkiem do weryfikacji systemów e-nauczania i dostosowania procesu kształcenia do potrzeb i możliwości studentów z niepełnosprawnościami, wymaga to jednak dalszej eksploracji badanego zjawiska. 


\section{BIBLIOGRAFIA}

Domagała-Zyśk, E. (red.), (2020). Zdalne uczenie się i nauczanie a specjalne potrzeby edukacyjne. $Z$ doświadczeń pandemii COVID-19. Wydawnictwo Episteme.

Gajdzica, Z. (2015). Student z niepełnosprawnością w przestrzeni szkoły wyższej - pomiędzy pedagogiką długu a pedagogiką wspólnotowości. Rocznik Lubuski, 41(2), 219-229.

Gulati, B. (2020). Organizacja edukacji zdalnej dla studentów z niepełnosprawnościami - rekomendacje. W: E. Domagała-Zyśk (red.), Zdalne uczenie się i nauczanie a specjalne potrzeby edukacyjne. Z doświadczeń pandemii COVID-19 (165-194). Wydawnictwo Episteme.

Plichta, P. (2020). Różne konteksty nierówności cyfrowych a wyzwania dla zdalnej edukacji - propozycje rozwiązań. W: J. Pyżalski (red.), Edukacja w czasach pandemii wirusa COVID-19. Z dystansem o tym, co robimy obecnie jako nauczyciele (70-80). Wydawnictwo EduAkcja.

Sztobryn-Giercuszkiewicz, J. (2016). Alter idem - student z niepełnosprawnością w systemie szkolnictwa wyższego. W: E. Zakrzewska-Manterys, J. Niedbalski (red.), Samodzielni, zaradni, niezależni. Ludzie niepełnosprawni w systemie polityki, pracy i edukacji (99-145). Wydawnictwo Uniwersytetu Łódzkiego.

Sztobryn-Giercuszkiewicz, J. (2020). Badać - nie wykluczając. Rozważania nad „metodologią dostępności. W: G. Całek, J. Niedbalski, D. Żuchowska-Skiba (red.), Jak badać zjawisko niepetnosprawności. Szanse i zagrożenia założeń teoretycznych i metodologicznych studiów nad niepełnosprawnościa (97-110). Wydawnictwo Uniwersytetu Łódzkiego.

\section{AKTY PRAWNE}

Konwencja ONZ o prawach osób niepełnosprawnych. Dz.U. 2012 poz. 1169.

Ustawa z dnia 20 lipca 2018 r. Prawo o szkolnictwie wyższym i nauce. Dz.U. 2018 poz. 1668

Ustawa z dnia 19 lipca 2019 r. o zapewnieniu dostępności osobom ze szczególnymi potrzebami. Dz.U. 2019 poz. 1696. 